Research note

\title{
They can dig it: semifossorial habits of the Mexican small-eared shrew (Mammalia: Cryptotis mexicanus)
}

\author{
Ellas pueden excavar: hábitos semifosoriales de la musaraña mexicana de orejas cortas \\ (Mammalia: Cryptotis mexicanus) \\ Lázaro Guevara
}

Museo de Zoología Alfonso L. Herrera, Departamento de Biología Evolutiva, Facultad de Ciencias, Universidad Nacional Autónoma de México, Apartado postal 70-399, 04510 Ciudad de México, Mexico

Received 16 October 2015; accepted 25 May 2017

Available online 6 November 2017

\begin{abstract}
Some small-eared shrews, genus Cryptotis, display modifications of the forelimb that have been interpreted as an adaptation for burrowing. As most of the species in the genus inhabit areas with poor accessibility and it is difficult to obtain direct observations in the wild, digging behavior remains unknown. This short note presents observational data under semi-natural conditions for the Mexican small-eared shrew that support the hypothesis of semifossoriality related to the functional morphology of its forelimb. These findings can provide clues about the assembly of shrew communities, particularly regarding foraging modes and niche partitioning.

(C) 2017 Universidad Nacional Autónoma de México, Instituto de Biología. This is an open access article under the CC BY-NC-ND license (http://creativecommons.org/licenses/by-nc-nd/4.0/).
\end{abstract}

Keywords: Behavior; Cryptotis; Digging; Eulipotyphla; Insectivora

\section{Resumen}

Algunas especies de musarañas de orejas cortas, género Cryptotis, exhiben modificaciones estructurales en el esqueleto poscraneal que han sido interpretadas como adaptaciones para excavar. Debido a que la mayoría de las especies del género habitan en zonas de difícil acceso y por la dificultad de obtener observaciones directas en la vida silvestre, el comportamiento de excavación es desconocido. Aquí se presentan observaciones bajo condiciones seminaturales en la musaraña mexicana de orejas cortas que apoyan la hipótesis de semifosorialidad relacionada con la morfología funcional de las extremidades anteriores. Estas observaciones pueden brindar pistas sobre el ensamble de las comunidades de musarañas, en particular con respecto a los modos de forrajeo y la repartición del nicho.

(C) 2017 Universidad Nacional Autónoma de México, Instituto de Biología. Este es un artículo Open Access bajo la licencia CC BY-NC-ND (http://creativecommons.org/licenses/by-nc-nd/4.0/).

Palabras clave: Comportamiento; Cryptotis; Excavación; Eulipotyphla; Insectivora

Shrews (Eulipotyphla, Soricidae) are aggressive predators with a voracious appetite and a constant need to forage (Churchfield, 1990). However, little ecological and behavioral information is available for the species inhabiting the American tropics. With over 40 species, Cryptotis is one of the most diverse

E-mail address: 11g@st.ib.unam.mx

Peer Review under the responsibility of Universidad Nacional Autónoma de México. and widespread genera of shrews in the New World (Guevara, Sánchez-Cordero, León-Paniagua, \& Woodman, 2014). Most Cryptotis species occur in cold and humid environments and are mainly distributed throughout tropical montane forests (Guevara, Cervantes, \& Sánchez-Cordero, 2015; Woodman et al., 2012), which might be related to a high abundance and variety of prey for shrews, such as worms and insects. It has been hypothesized that some modifications in postcranial morphology permit some species of Cryptotis to dig and forage in tunnels (Choate, 1970; Woodman \& Morgan, 2005). Recent 
morphological studies of limb skeletons among Cryptotis have revealed graded transitions in these adaptations from semifossorial to more fossorial behavior (Woodman \& Gaffney, 2014; Woodman \& Morgan, 2005). Unfortunately, because most of the species of the genus inhabit areas with poor accessibility and capture success is relatively low compared with that of other small mammals, little is known about the digging behavior of Cryptotis species based on direct observations (Díaz-de Pascual \& de Ascencao, 2000; Woodman \& Gaffney, 2014).

One species for which an intermediate mode of semifossoriality has been inferred is the Mexican small-eared shrew (Cryptotis mexicanus): a small-sized shrew with an average body mass of $7.5 \mathrm{~g}$ and head-body length of $70 \mathrm{~mm}$, a mole-like form, and enlarged forefeet and elongated foreclaws (Woodman \& Gaffney, 2014; Woodman \& Timm, 2000). During a shortterm survey using pitfall traps, 7 shrews were collected in July 2015 from San Antonio Matlahuacales, in the municipality of Chignahuapan, Puebla, Mexico $\left(19^{\circ} 41.871^{\prime} \mathrm{N}, 98^{\circ} 05.592^{\prime}\right.$ W; $2900 \mathrm{~m}$ ). Permits for fieldwork were issued by the local administration from Chignahuapan and the Secretaría de Medio Ambiente y Recursos Naturales (Semarnat; FAUT 006), following the American Society of Mammalogists guidelines on sample care and management of specimens (Sikes, Gannon, \& The Animal Care and Use Committee of the American Society of Mammalogists, 2011). Specimens exhibited the measurements and diagnostic characteristics of $C$. mexicanus according to Woodman and Timm (2000) and Guevara et al. (2014). The microhabitat where shrews were found consisted of pine and oak trees and a dense fog that covered the forest area, with a slope ranging from 30 to 40 degrees. The ground had a litter layer about $5 \mathrm{~cm}$ thick, formed mainly by litter from pine and oak. The only 2 individuals collected alive were used for behavioral observations, and were immediately transported to Mexico City and introduced to a terrarium $(90 \times 60 \times 30 \mathrm{~cm})$ with a layer of $7 \mathrm{~cm}$ of soil and $2 \mathrm{~cm}$ of leaf litter and moss, simulating the soil conditions of the collection site. Ad libitum feeding in captivity consisted of live crickets, mealworms, earthworms, and fresh beef. Water was supplied through a container and ice cubes. Observations, videos, and photographs were recorded for short periods along the day for 15 days in a row.

The shrews showed high burrowing activity, and spent nearly all of their time underground. They ate large quantities of food every day, from 80 to $100 \%$ of their body weight, and were extremely active from the first hour after sunset to until about $2 \mathrm{~h}$ after dawn. The 2 individuals commonly made and used tunnels at a depth of $2-3 \mathrm{~cm}$ from the soil surface through vigorous use of the manus and claws (Fig. 1a, 1b). To catch prey, the shrews alternated between subterranean tunnels and surface runways. When the shrews used tunnels, they dug open holes to the surface to breathe and find prey (Fig. 1c). Once they found their prey, they pursued them immediately above surface, which could be motivated by sense of smell or taste (Fig. 1d; Saarikko, 1989). Shrews also stored raw beef underground when they had enough food to consume immediately. Food hoarding behavior might be beneficial if it reduces the frequency of interactions with competitors or predators, or when food supply is unpredictable (Rychlik \& Jancewicz, 2002).
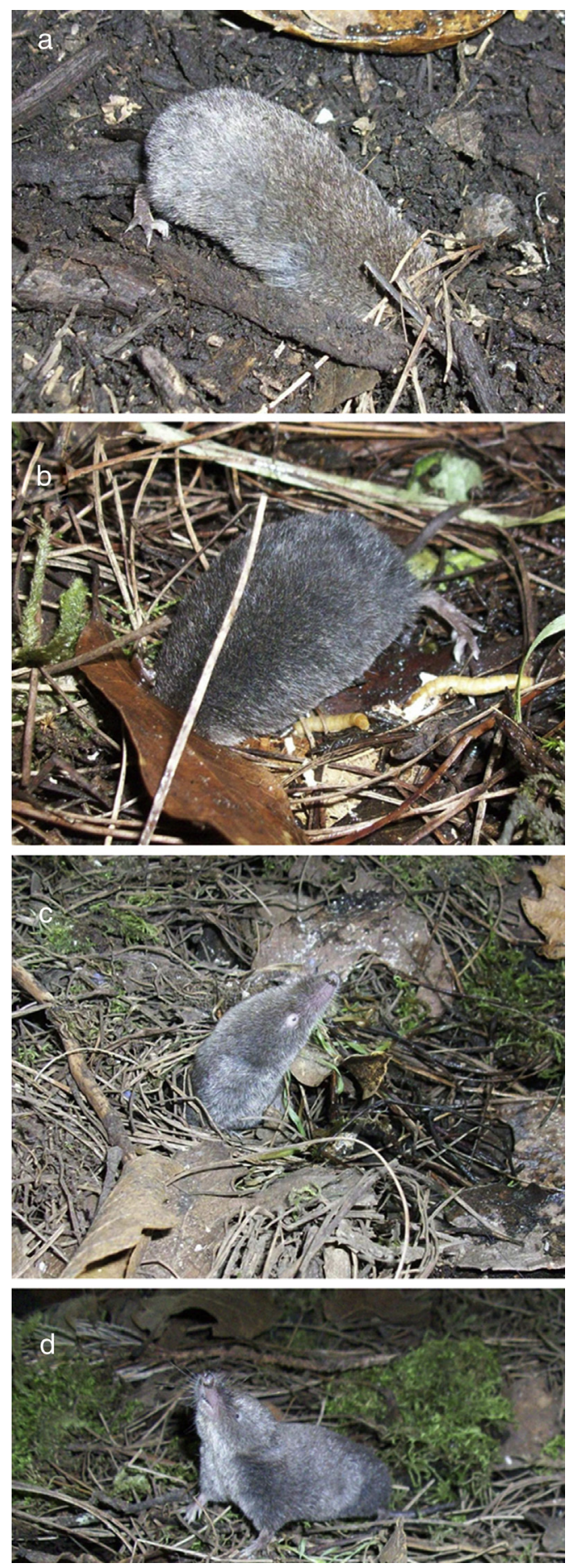

Figure 1. Digging and foraging behavior of the Mexican small-eared shrew, Cryptotis mexicanus, under semi-natural conditions.

The observations presented here support the hypothesis that the mole-like form and additional characters of the forelimbs in C. mexicanus are adaptations for burrowing ability and a semifossorial life-style in the wild. C. mexicanus occurs in cloud and pine-oak forests and has been found to be not only sympatric but also syntopic with other soricids (Guevara et al., 2015). A recent study indicates that $C$. mexicanus can live under similar environmental conditions with C. magnus, C. parvus, 
C. goldmani, S. ixtlanensis, S. salvini, S. veraepacis, or $S$. macrodon (Guevara et al., 2015); however, at a fine scale, evidence of niche differentiation could be found in terms of foraging mode and prey selection (Churchfield, 1990; Churchfield \& Rychlik, 2006). Therefore, observations of substrate use and locomotor behavior can provide information on coexistence and niche partitioning among species of shrews, as well as the ecological requirements of this little-known semifossorial mammal.

I wish to express my thanks to Dra. R. Mata-López for her leadership in the project on parasites of wild mammals. Financial support was provided by the Programa de Apoyo a Proyectos de Investigación e Innovación Tecnológica (PAPIIT-UNAM IN220113). I also thank Jamie Kass for the friendly English corrections. V. Sánchez-Cordero for providing the permit for collecting mammals. I dedicate this contribution to Fernando A. Cervantes, teacher, colleague and friend, whose enthusiasm has promoted the knowledge of Mexican shrews. And I thank my wife Steph for sharing this wonderful journey with me.

\section{References}

Choate, J. (1970). Systematics and zoogeographic of Middle American shrews of the genus Cryptotis. University of Kansas Publications, Museum of Natural History, 19, 195-317.

Churchfield, S. (1990). The natural history of shrews. Cornell University Press.

Churchfield, S., \& Rychlik, L. (2006). Diets and coexistence in Neomys and Sorex shrews in Białowieża forest, eastern Poland. Journal of Zoology, 269, 381-390.
Díaz-de Pascual, A., \& De Ascencao, A. A. (2000). Diet of the cloud forest shrew Cryptotis meridensis (Insectivora: Soricidae) in the Venezuelan Andes. Acta Theriologica, 45, 13-24.

Guevara, L., Sánchez-Cordero, V., León-Paniagua, L., \& Woodman, N. (2014). A new species of small-eared shrew (Mammalia, Eulipotyphla, Cryptotis) from the Lacandona rain forest, Mexico. Journal of Mammalogy, 95, 739-753.

Guevara, L., Cervantes, F. A., \& Sánchez-Cordero, V. (2015). Riqueza, distribución y conservación de los topos y las musarañas (Mammalia, Eulipotyphla) de México. Therya, 6, 43-68.

Rychlik, L., \& Jancewicz, E. (2002). Prey size, prey nutrition, and food handling by shrews of different body sizes. Behavioral Ecology, 13, 216-223.

Saarikko, J. (1989). Foraging behaviour of shrews. Annales Zoologici Fennici, 26, 411-423.

Sikes, R. S., Gannon, W. L., \& The Animal Care and Use Committee of the American Society of Mammalogists. (2011). Guidelines of the American Society of Mammalogists for the use of wild mammals in research. Journal of Mammalogy, 92, 235-253.

Woodman, N., \& Gaffney, S. A. (2014). Can they dig it? Functional morphology and semifossoriality among small-eared shrews, genus Cryptotis (Mammalia, Soricidae). Journal of Morphology, 275, 745-759.

Woodman, N., Matson, J. O., McCarthy, T. J., Eckerlin, R. P., Bulmer, W., \& Ordóñez-Garza, N. (2012). Distributional records of shrews (Mammalia, Soricomorpha, Soricidae) from Northern Central America with the first record of Sorex from Honduras. Annals of Carnegie Museum, 80, 207-237.

Woodman, N., \& Morgan, J. J. P. (2005). Skeletal morphology of the forefoot in shrews (Mammalia: Soricidae) of the genus Cryptotis, as revealed by digital X-rays. Journal of Morphology, 266, 60-73.

Woodman, N., \& Timm, R. M. (2000). Taxonomy and evolutionary relationships of Phillips' small-eared shrew, Cryptotis phillipsii (Schaldach, 1966), from Oaxaca, Mexico (Mammalia: Insectivora: Soricidae). Proceedings of the Biological Society of Washington, 113, 339-355. 